\title{
UNIVERSITY STUDENTS' TAX MORALE: A STUDY OF GENDER WITHIN THE UNIVERSITY OF ALICANTE, SPAIN
}

\author{
C.P. Sarasa ${ }^{1}$, J. Sarasa-Pérez ${ }^{2}$ \\ ${ }^{1}$ Universitat Politècnica de València (SPAIN) \\ ${ }^{2}$ University of Alicante (SPAIN)
}

\begin{abstract}
The objective of this study is to analyse the tax conscience or tax morale of a group of university students of the University of Alicante, Spain. More specifically, the research aims to find whether university students have tax morale and whether there is any significant difference between men and women. The research mainly attempts to identify the degree of satisfaction and knowledge of the taxation system among university students as factors that influence the degree of tax awareness and tax compliance. The study analyses these influencing factors and then evaluates the fiscal morale of the participants based on indicators of their own conduct and the perceived social behaviour.
\end{abstract}

To know the findings of this research will make it possible to design better educational actions that could exercise a positive influence on students' tax morale. In addition, it will allow us to know if it is necessary to do any adjustment in these educational actions because of gender reasons.

Keywords: Tax morale, Tax system, Undergraduate, Student, Spain, Regulation, Education, University.

\section{INTRODUCTION}

Tax obligations are considered to be powerful tools of solidarity and social cohesion. One of the cornerstones of democratic society in the organisation of its social fabric is tax solidarity. Tax regulations form part of a series of social norms which adult individuals must adhere to in a democratic society.

In addition to the conscience of the individual, a determining factor of the degree to which these taxation regulations are fulfilled is the level of tax awareness of a society as this directly affects the inclination of those who voluntarily comply and reject tax fraud.

Another highly influential factor is the complexity or, on the contrary, the simplicity of the system. The Spanish taxation system is complex and largely unknown to most citizens as is the financial activity arising from this taxation system whereby public bodies receive income to finance the public spending to ensure the social wellbeing of the population.

This constitutes the framework for our study which seeks to analyse the tax conscience or morale of university students. Tax morale is closely related to what others define as taxpayer ethics, or what Song and Yarbrough [1] define as "the norms of behaviour governing citizens as taxpayers in their relationship with the government". More specifically, it seeks to determine whether university students of management and business have tax morale and, whether there is any difference between the two sexes. It attempts to identify the degree of interest, satisfaction and knowledge of the taxation system among university students as factors that influence the degree of tax awareness and compliance. After a brief literature review, the study will analyse these influencing factors and then evaluate the fiscal morale of the participants of the survey based on indicators of their own conduct and the perceived social behaviour. Finally, conclusions will be drawn and the bibliographical sources will be listed.

\section{LITERATURE REVIEW}

The earliest research projects in the field of tax morale were carried out in the 1960s, in the Cologne School of Tax Psychology. These projects included research conducted by Schmölders [2] on the tax morale of workers. The tax morale of the workers that arose from this study became a measure of tax awareness. Meanwhile Strümpel [3] focused his analysis on the tax morale of European taxpayers.

We can also refer to other more recent studies on tax compliance which mention the concept of tax morale. For example, Feld and Frey [4] analyse tax compliance in 26 Swiss cantons and propose a 
model in which the dependent variable is tax morale with the significant variables being the degree of participation in government and particularly the choice of public assets and the way in which taxpayers are treated.

Meanwhile, Alm and Torgler [5] compare different European countries with the United States and conclude that there are differences in tax morale due to cultural differences between countries. The authors perceive a higher degree of tax morale in northern European countries than in those in the south (France, Italy or Spain).

Drawing from data in the World Values Survey and European Values Survey 1981-2000, MartinezVazquez and Torgler [6-7] have carried out an analysis of the Spanish case. The results reveal that there is greater tax morale among women, older people and members of the lower social classes. With regard to research conducted on the female sex, we can highlight the study conducted by Alarcón et al. [8] The results of this study reveal the opposite to those of Martinez-Vazquez and Torgler.

It is also worth mentioning Molero and Pujol [9], who carried out a survey of University students and constituted one of the most complete questionnaires for identifying the determining factors of tax morale in Spain. This study concludes that the more it is believed that only a few individuals commit tax fraud the greater the tax morale. In addition, the better perceived the quality of the services provided by the public sector and satisfaction of the taxpayer, the higher the tax morale.

This study relates to this research insofar as it analyses the tax morale of a group of undergraduate university students after receiving a specific course on taxation and seeks to identify indicators of behaviour and influential factors and to determine whether differences exist between men and women.

\section{CASE STUDY}

The procedure followed in this analysis comprised the collection of data through surveys, which were then organised using descriptive statistics, discriminant analysis and an analytical summary of the variables studied.

The sample used was composed of 157 valid surveys corresponding to students of management and business courses at the University of Alicante (UA).

Given that the study analyses whether any differences exist between women and men in terms of tax awareness among university students, an econometric analysis was carried out in order to determine if the "gender" variable is significant in explaining the model. The discriminant model is used for this analysis which, as a dependence analysis technique, implements a model of causality in which the endogenous variable is a qualitative variable and the independent or exogenous variables are qualitative or quantitative variables, as is our case.

\subsection{The Spanish taxation system: degree of knowledge and satisfaction}

Tax awareness can only exist if citizens hold an interest in the financial activity of the state and other public bodies and have knowledge of the taxation system. Different public opinion studies [10] indicate that the average citizen has a fairly limited knowledge of public affairs, particularly the more complex matters such as economic policy.

With respect to this aspect, the questionnaire ask the following question:

Question 1. "From your point of view, do you know the regulations (rules that should be followed) regarding the main taxes that you pay? Options: "1) I do not know them at all; 2) I have a limited knowledge of them; 3) I have an average knowledge of them; 4) I have a good knowledge of them; 5) Don't know / no answer."

$71.3 \%$ of those surveyed say "I have a limited knowledge of them" (maybe they are conscious that the just only have coursed one subject about taxation issues). $24.2 \%$ have an average knowledge of the regulations.

The participants in the survey were also asked about the tax pressure in Spain:

Question 2. "Would you say that what we pay in tax in Spain could be considered a large amount?"

In response to this question, $65 \%$ of those surveyed said that they considered that in Spain a "large amount" of tax is paid 
Question 3. "In comparison with other European countries, do you think that in Spain we pay more taxes?"

$21 \%$ of the respondents completely disagree with this statement. $26.1 \%$ agree to some extent, $17.8 \%$ are quite agree and $15.3 \%$ are very much in agreement

In this section, the Wilks' lambda statistic has a P-value of $<0.05 \alpha$, so the "gender" variable is significant with a $95 \%$ confidence interval. $27.6 \%$ of the women completely disagree with this statement and the same percentage agrees to some extent. $13.8 \%$ are quite agree and $17.2 \%$ are very much in agreement. For men, percentages are $12.9 \%, 24.3 \%, 22.9 \%, 12.9 \%$, respectively ( $27.1 \%$ did not know or did not answer).

Question 4. "In comparison with other European countries, do you think that in Spain we pay the same amount of taxes?"

$43.9 \%$ of the respondents completely disagree with this statement. $29.3 \%$ agree to some extent, $7.6 \%$ are quite agree and no one is very much in agreement. $19.1 \%$ did not know or did not answer the question.

Question 5. "In comparison with other European countries, do you think that in Spain we pay less tax?"

$49.7 \%$ of the participants completely disagree with this idea. $21.7 \%$ agree to some extent, $5.7 \%$ are quite agree and $1.9 \%$ are very much in agreement.

Tax morale is directly affected by the degree of satisfaction with the distribution of income obtained through taxation. Therefore, the following question was asked:

Question 6. "What is your level of satisfaction with respect to public services and provisions (on a state, regional and local level) obtained in exchange for the tax that you pay?" "1) Completely unsatisfied; 2) A little satisfied; 3) Quite satisfied; 4) Highly satisfied; 5) Don't know / no answer."

$48.4 \%$ of those surveyed say that they are a little satisfied with the State. Another important result is that $26.8 \%$ respond that they are completely unsatisfied. $19.7 \%$ say that they are quite satisfied. Only $1.9 \%$ is highly satisfied. Another $3.2 \%$ do not know or do not answer.

With respect to the Regional Government, the percentages of the level of satisfaction with the provisions received are: $40.8 \%$ completely unsatisfied; $39.5 \%$ a little satisfied; $15.3 \%$ quite satisfied; $0.6 \%$ highly satisfied.

And in terms of the Local Government: $42 \%$ are a little satisfied; $27.4 \%$ completely unsatisfied; $21.7 \%$ quite satisfied; $3.8 \%$ highly satisfied.

From this question we can observe that, of the three administrations analysed, the Regional Government is the worst valued administration.

To conclude this section, and bearing in mind that an adequate tax awareness is based on the interest in, knowledge and perception of the taxation system, we can observe that almost $72 \%$ of participants say that they have a poor knowledge of the tax regulations. We think that this perception is the result of the fact that they have recently introduce to taxation matters (they have just finished their first subject about taxes). The perceived complexity of the system depends not only on the characteristics of taxpayer, but also on the organisation and structure of the system itself. Its decentralisation into different levels of government (state, regional and local) and the distribution of the tax burden between them contributes to this feeling of complexity, worsened by the ignorance of students largely due to the lack of previous education in taxation. The difficulty of the system may give rise to a noncompliance with obligations, blurring the perception that tax obligations are a civic duty within a democratic fiscal culture.

When asked about taxes paid in Spain, $65 \%$ of the sample believes that a large amount of tax was paid. With respect to the question related to other countries in the EU, the statement with greater support was "In comparison with other European countries in Spain we pay more taxes" $(59.21 \%$ agree to some extent, with differences between men and women).

Finally, with regard to the perception of the taxation system, we can see that the people participating in the survey are, on the whole, more dissatisfied with the provisions of their Regional Government than those provided by the Local or State governments. 


\subsection{Tax morale: indicators}

As previously mentioned, this study seeks to assess the tax morale of the respondents to the survey based on a series of questions which act as indicators of behaviour. It is a way of indirectly asking about tax awareness.

Question 7. "In your opinion, which of these behaviours would be most reprehensible? 1) Someone fails to pay $€ 6,000$ to the tax authorities; 2) Someone stole $€ 100$ from you."

$65 \%$ of the participants considered that failing to pay $€ 6,000$ to the tax authorities was most reprehensible.

Question 8. This question addresses the hypothesis of changing residence in order to pay less tax, with the idea of indirectly measuring the honesty of the students with respect to taxation. The responses received reveal that $20.4 \%$ would be willing to change their residence, $70.7 \%$ would not (the remaining $8.9 \%$ don't know or did not answer).

Finally, the respondents were asked about responsibility when paying tax in the following terms:

Question 9. "With respect to paying tax, I believe that Spanish men and women are: 1) Hardly aware or responsible; 2) Not very aware or responsible; 3) Quite aware and responsible; 4) Highly aware and responsible; 5) Don't know / no answer."

$59.2 \%$ of the sample considers Spanish men and women to be not very aware or responsible when paying tax; $26.1 \%$ believe that they are hardly aware or responsible; $10.8 \%$ think that they are quite aware and responsible; and $0 \%$ see Spaniards as being highly aware and responsible.

This perception does not coincide with the data obtained through the survey conducted by Spain's Centre of Sociological Research (CIS) [11], which generated the following results for the same question: $37.9 \%$ of Spaniards are not very aware or responsible: $12.8 \%$ believe that they are hardly aware or responsible; $34.4 \%$ of the sample consider that they are quite aware and responsible; and $8.9 \%$ consider Spaniards to be highly aware and responsible. Therefore, the results of our survey are much more critical than those obtained by the CIS.

A P-value of $>0.05 \alpha$ is observed which indicates that there are no differences with respect to gender.

To conclude this section, in an assessment of tax morale based on a series of representative questions about own behaviour and perceived social behaviour, we can indicate that $65 \%$ of the survey participants considered that failing to pay $€ 6,000$ to the tax authorities was the most reprehensible conduct. A considerable percentage, (35\%) believe that having $€ 100$ stolen from them is more reprehensible. This response reveals the perception that some people have that when tax fraud is committed no-one loses because "the money doesn't belong to anyone". However, if $€ 100$ is stolen from us, the damage is direct. It is worth highlighting that the results for this point are somewhat better and more encouraging than those obtained in previous studies with the same variable.

When asked about the idea of changing residence in order to pay less tax, the gender variable was not significant, contrary to the results of a previous study developed with students of different undergraduate degree courses in Engineering and Management and Business Studies at the Alcoy Campus of the Universitat Politècnica de València (UPV) [12]. In that case, the study revealed that less men than women were willing to change their residence for this reason. The female respondents who said that they would change their residence practically doubled the men inclined to make the same choice.

And finally, with respect to the question regarding the perceived responsibility of Spanish society in relation to the payment of taxes, there is a strikingly high perception of fiscal irresponsibility (more than $85 \%)$ which has a negative influence on tax morale. This result is more negative than the result obtained by the CIS for the same question.

\section{CONCLUSIONS}

This study analyses the tax morale of Spanish university students based on the results of a survey carried out on a group of undergraduates and seeks to detect if there are differences in this morale between the sexes. 
An adequate tax morale is based on an adequate self-awareness and a perceived prevalence of correct social behaviour. It is also based on an interest in and adequate perception and knowledge of the taxation system.

After assessing tax morale based on individual behaviour the results obtained reveal that the gender variable is not significant in the case of changing residence in order to pay less tax, on contrary to the results of a previous study [12].

With regard to the question addressing the perceived responsibility of Spanish citizens with respect to the payment of taxes, we can highlight that a high proportion of the participants (more than $85 \%$ ) say that they perceive a high level of fiscal irresponsibility, which, in turn has a negative effect on tax morale. The results obtained in this survey are more negative than those obtained by the CIS for the same question and those obtained in a similar study conducted at UPV [12]. As for the differences between men and women, the results reveal that both have the same perspective of the responsibility of Spanish citizens.

However, there are differences in perception between the men and women with respect to whether more tax is paid in Spain than in other EU countries. More specifically, $58.6 \%$ of the women consider that in Spain more taxes are paid.

In relation to the degree of satisfaction in the distribution of the income obtained through taxation as a variable that affects tax morale, the students surveyed on the whole (there are no differences on grounds of sex) said that they were more dissatisfied with the services provided by their Regional Government than the State or Local Governments..

Finally, the results of the survey reveal that both sexes have the same level of knowledge of the taxation system. As this knowledge is a variable that directly influences tax morale, the taxation system should form part of the curriculum in the Spanish education system in a significant way and form an early age. In this way, citizens would have a better tax awareness. The family has a decisive influence on the socialisation of citizens, but this influence is shared with society and other institutions, including the education system. This factor is decisive for tax compliance and to reduce possible differences based on gender. It should be taken into account that tax morale does not emerge naturally but is a social product and, as such, is the result of education.

\section{REFERENCES}

[1] Song, Y., Yarbrough T.E,. "Tax Ethics and Taxpayer Attitudes: A survey", Public Administration Review, no. 38, pp. 442-457, 1978.

[2] Schmölders, G., "Survey Research in Public Finance: A Behavioral Approach to Fiscal Theory", Public Finance no. 25, pp. 300-306, 1960.

[3] Strümpel, B., "The Contribution of Survey Research to Public Finance", In Quantitative Analysis in Public Finance. Ed. Praeger Publishers. New York. pp. 14-32, 1969.

[4] Feld, L.P., Frey, B.S., "Trust breeds trust: How taxpayers are treated", Economics of Governance, no. 3, pp. 87-99, 2002.

[5] Alm, J., Torgler, B., "Culture Differences and Tax Morale in the United States and Spain", Working paper no. 33, Center for Research in Economics, Management and Arts, 2005.

[6] Martinez-Vazquez J., Torgler, B., "The Evolution of Tax Morale in Modern Spain", Working paper no. 33. Center for Research in Economics, Management and Arts, 2005.

[7] Martinez-Vazquez, J., Torgler, B., "The evolution of Tax Morale in modern Spain", Journal of Economic Issues (pre-1986), no. 43 (1):1, 2009.

[8] Alarcón García, G., Quiñones Vidal, E., Sánchez Meca, J., Peñaranda Ortega, M., "Conciencia y fiscalidad en las mujeres españolas" <

http://www.upo.es/congresos/export/sites/congresos/economiafeminista/documentos/Area2/Glo ria_Alarcon.pdf > [30/06/2016].

[9] Molero, J.C., Puyol, F., "Walking Inside the Potential Tax Evader's Mind: Tax Morale Does Matter", Journal of Business Ethics, no. 105, pp. 151-162, 2012. 
[10] Instituto de Estudios Fiscales. IEF., Opiniones y actitudes fiscales de los españoles en 2012 < http://www.ief.es/documentos/recursos/publicaciones/documentos_trabajo/2013_21.pdf > [10/05/2016], 201).

[11] Centro de Estudios Sociológicos. CIS., Opinión pública y política fiscal. < http://www.cis.es/cis/export/sites/default/-Archivos/Marginales/3020_3039/3034/es3034mar.pdf $>$ [12/07/2016], 2014.

[12] Sarasa, C.P., Sarasa-Pérez, J., Moya-Auñón, B.A, "Students' tax morale in Spanish universities: Does gender matter?", ICERI2015 Proceedings. pp. 4516-4521, 2015. 